ANALISIS POTENSI DAN EFEKTIFITAS PAJAK HOTEL SERTA FAKTORFAKTOR YANG MEMPENGARUHI PENERIMAAN PAJAK HOTEL DI KOTA BANDUNG

\title{
SKRIPSI
}

Diajukan untuk memenuhi sebagian syarat untuk memperoleh gelar Sarjana Ekonomi pada Program Studi Akuntansi

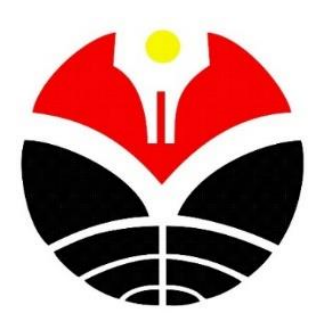

Disusun oleh:

Muhamad Iqbal Naimul Firdaus

1506710

PROGRAM STUDI AKUNTANSI

FAKULTAS PENDIDIKAN EKONOMI DAN BISNIS

UNIVERSITAS PENDIDIKAN INDONESIA

2019 


\section{ANALISIS POTENSI DAN EFEKTIFITAS PAJAK HOTEL SERTA FAKTOR- FAKTOR YANG MEMPENGARUHI PENERIMAAN PAJAK HOTEL DI KOTA BANDUNG}

Oleh

Muhamad Iqbal Naimul Firdaus

Sebuah skripsi yang diajukan untuk memenuhi salah satu syarat memperoleh gelar Sarjana Ekonomi pada Program Studi Akuntansi

Fakultas Pendidikan Ekonomi dan Bisnis

(C) 2019 Muhamad Iqbal Naimul Firdaus

Universitas Pendidikan Indonesia

Agustus 2019

Hak Cipta dilindungi undang - undang

Skripsi ini tidak boleh diperbanyak seluruhnya atau sebagian,

Dengan dicetak ulang, difoto kopi, atau cara lainnya tanpa ijin dari peneliti 


\section{LEMBAR PENGESAHAN}

ANALISIS POTENSI DAN EFEKTITIAS PAJAK HOTLL SERTA PAKTOR FAKTOR YASAS

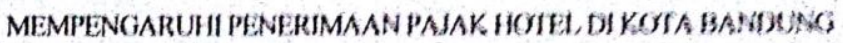

SKRIPSI

Disusun oleh:

Muhamad Iqbal Naimul Firdaus

1506710

Disctujui dan disahkan oleh Pembimbing :

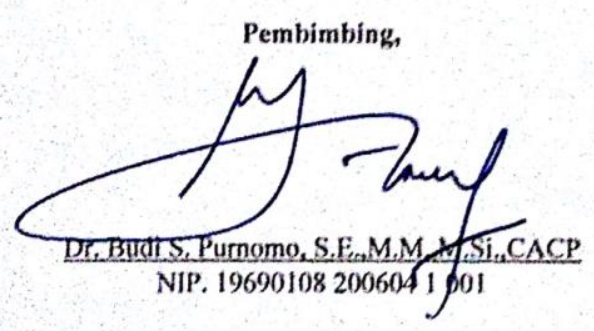

Mengetahui,

Ketua Program ftudi Akuntansi

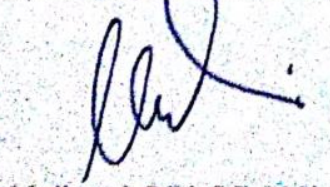

Dr. Flis Mediawati, S.Pd S.E,MSi AK.CA

NIP. 198201232005012002 


\section{PERNYATAAN KEASLIAN NASKAH}

Dengan ini saya menyatakan bahwa skripsi dengan judul "Analisis Potensi dan Efektifitas Pajak Hotel Serta Faktor-Faktor yang Mempengaruhi Penerimaan Pajak Hotel di Kota Bandung” beserta seluruh isinya adalah benar-benar karya sendiri dan saya tidak melakukan penjiplakan atau pengutipan dengan cara-cara yang tidak sesuai dengan etika keilmuan yang berlaku dalam masyarakat. Atas pernyataan ini, saya siap menanggung risiko/sanksi yang dijatuhkan kepada saya apabila di kemudian hari ditemukan adanya pelanggaran terhadap etika keilmuan dalam karya saya ini, atau ada klaim dari pihak lain terhadap keaslian naskah ini.

Bandung, $\quad$ Agustus 2019 Yang membuat pernyataan,

Muhamad Iqbal Naimul Firdaus 


\section{UCAPAN TERIMA KASIH}

Alhamdulillahirabbil'alamin. Segala puji dan syukur ke hadirat Illahi Rabbi karena curahan rahmat serta karunia-Nya, peneliti mendapatkan kemudahan dan kelancaran dalam menyelesaikan skripsi ini dengan baik. Shalawat serta salam semoga selalu tercurah kepada Rasulullah SAW, juga pada keluarganya, pada sahabatnya dan seluruh umatnya yang setia sampai akhir zaman.

Hadirnya skripsi ini merupakan akhir dari penantian panjang peneliti selama kurang lebih empat tahun. Alhamdulillah dengan ijin Allah Ta'ala, peneliti mampu menyelesaikan penelitian ini. Atas keberhasilan ini tentunya melibatkan banyak pihak yang telah memberikan bantuan, motivasi dan do'a terbaik. Oleh karena itu, dalam kesempatan ini peneliti ingin menyampaikan rasa terima kasih yang sebesar-besarnya kepada :

1. Bapak Prof. Dr. H. R Asep Kadarohman selaku Rektor Universitas Pendidikan Indonesia;

2. Prof. Dr.H. Agus Rahayu, MP. selaku Dekan Fakultas Pendidikan Ekonomi dan Bisnis;

3. Ibu Dr. Elis Mediawati, S.Pd., SE., M.Si, Ak, CA., selaku Ketua Program Studi Akuntansi yang telah memberikan dukungan selama kegiatan perkuliahan;

4. Bapak Budi S. Purnomo, S.E., MM., M.Si, selaku pembimbing yang tak pernah lelah, bosan dan telah meluangkan waktu serta pikirannya dalam memberikan bimbingan, arahan dan masukan serta semangat dan doa terbaik bagi peneliti sehingga peneliti dapat menyelesaikan skripsi dengan baik;

5. Ibu Hanifa Zulhaimi, S.Pd., M.Ak selaku pembimbing akademik yang senantiasa mengarahkan, membimbing dan membersamai kami selama menempuh pendidikan di Universitas Pendidikan Indonesia;

6. Prof. Dr. H. Memen Kustiawan, S.E., M.Si., Ak. CA, Ibu Dr. Hj. Alfira Sofia, ST., MM, dan Ibu Dr. Hj. Ida Farida Adi Prawira, S.E., M.Si, selaku dosen penelaah dan penguji yang telah memberi masukan serta meluangkan waktu dan pemikirannya selama penyelesaian skripsi ini;

7. Seluruh dosen dan staf Program Studi Akuntansi, yang telah memberikan bimbingan, memberikan ilmu pengetahuan dan petunjuk sejak awal masa perkuliahan hingga akhir perkuliahan;

8. Staff tata usaha Program Studi Akuntansi Universitas Pendidikan Indonesia yang telah membantu kelancaran dan memberikan kemudahan dalam mengurus semua administrasi selama masa perkuliahan;

9. Seluruh Staf dan Pimpinan Biro Organisasi Sekretariat Daerah Provinsi Jawa Barat, tempat menimba ilmu selama Pendidikan Latihan Akademik, yang telah memberikan kelancaran dalam menyelesaikan studi;

10. Kedua orang tua peneliti tercinta Bapak Iyus Rusmana dan Ibu Emil Tuhfathul Jamillah, orang yang paling hebat di dunia ini, orang yang selalu tidak pantang menyerah dalam memberikan doa, bantuan, dukungan, kasih sayang, pengorbanan dan semangat di setiap langkah perjalanan peneliti dalam menuntut ilmu. Terimakasih telah bekerja keras agar anakmu ini bisa menyelesaikan studi sampai akhir. Semoga kelak anakmu ini dapat membalas jasa-jasa serta membahagiakan mama dan papa. Semoga Allah melimpahkan curahan rahmat dan kasih sayang-Nya; 
11. Ahmad Zaini Miftahul Fitri, kakak tercinta yang selalu mensupport peneliti berserta seluruh keluarga besar;

12. Perusahaan Grab dan Gojek yang telah memberikan kesempatan bagi peneliti untuk menjadi Mitra Driver. Banyak pengalaman yang peneliti dapat selama menjadi Mitra Driver, sekaligus menemani peneliti selama proses perkuliahan dan penyusunan skripsi dikala sedang bosan dan membutuhkan uang.

13. Teman-teman pria angkatan 2015 yang tidak bisa peneliti sebut namanya satu per satu, para "CUCUMBER" yang selalu menghibur peneliti selama perkuliahan maupun diluar perkuliahan. Kalian semua mengajarkan arti hidup untuk bisa menjadi pribadi yang lebih baik. Semoga silaturahmi kita tetap terjaga hingga ajal menjelang tiba.

14. Beben Beni, Hary Prasetyo, M. Imam Arifin, Muhammad Rijal, Oky Dwika, Ajeng Restu, Rifda Anbar, Anisa Kusumadewi, Aprilia Anggiani, Reni Damayanti, Nurul Yuliyani, dan Novi Fajrin, para camistri yang selalu memberikan keceriaan, kebahagiaan, semangat, dan motivasi selama perkuliahan.

15. Fauzan Fadhlurrahman dan Maulana Agung yang telah memberikan izin peneliti untuk tinggal sementara selama penyusunan skripsi di Apartemen Pendidik Bangsa.

16. Fahira Salsabila teman KKN yang selalu peneliti repotkan dengan ikut meng-print selama proses penyusunan skripsi dari awal sampai akhir. Semoga kebaikanmu dibalas oleh Allah berlipat ganda.

17. Teman-teman KKN UPI Desa Mekarsari Kec. Karangpawitan Kab Garut. Terimakasih, peneliti merasa mendapatkan pengalaman dan keluarga baru selama kegiatan KKN berlangsung;

18. Teman-teman Angkatan 2015, rekan seperjuangan, tempat berbagi dan menjadi keluarga kedua di Bandung, terima kasih atas segala kenangan, canda tawa dan semangat selama menempuh perkuliahan. Hal tersebut tidak terlepas dari Ketua Angkatan Akuntansi 2015 M. Imam Arifin, KAANG terbaik sehingga peneliti dapat merasakan kekeluargaan dalam berbagai perbedaan karakteristik individu dalam akuntansi 2015. Jangan pernah lupa dengan jargon kita "SOLIDARITAS TANPA BATAS" ;

Kepada semua pihak yang tidak dapat peneliti sebutkan satu per satu yang telah membantu peneliti baik secara langsung maupun tidak langsung dalam menyelesaikan skripsi maupun studi. Semoga Allah SWT senantiasa memberikan balasan yang tak terhingga kepada semua pihak yang telah membantu penulis. Semoga segala urusannya dapat dimudahkan dan dilancarkan oleh Allah SWT aamiin. 


\begin{abstract}
ABSTRAK
Analisis Potensi dan Efektifitas Pajak Hotel Serta Faktor-Faktor yang Mempengaruhi Penerimaan Pajak Hotel di Kota Bandung
\end{abstract}

Oleh:

Muhamad Iqbal Naimul Firdaus

1506710

Dosen Pembimbing

Budi S. Purnomo, S.E.,MM.,M.Si.,CACP

Penelitian ini bertujuan untuk mengetahui seberapa besar potensi dan efeketiftas pajak hotel di Kota Bandung tahun 2016-2018 serta mengetahui faktor yang mempengaruhi penerimaan pajak hotel di Kota Bandung. Metode penelitian yang digunakan dalam penelitian ini adalah metode deskriptif dan kuantitatif. Populasi pada penelitian ini adalah seluruh hotel yang terdapat di Kota Bandung. Metode pengambilan sampel pada penelitian ini adalah menggunakan metode sampel jenuh. Data sekunder diperoleh dari LKIP 2004-2018 dan Dinas Kebudayaan dan Pariwisata Kota Bandung. Pengujian hipotesis pada penelitian ini menggunakan analisis regresi linear berganda dengan alat bantu software SPSS 25. Hasil pengujian hipotesis menunjukkan bahwa (1) jumlah wisatawan berpengaruh positif terhadap penerimaan pajak hotel; (2) jumlah hotel tidak berpengaruh terhadap penerimaan pajak hotel. Berdasarkan perhitungan potensi dan efektifitas, hasilnya adalah potensi pajak hotel di Kota Bandung nilainya lebih rendah dibanding dengan realisasi pajak hotel, artinya bahwa pemungutan pajak hotel di Kota Bandung telah optimal dan efektifitas pajak hotel yang selalu diatas $100 \%$ artinya tingkat efektifitasnya sangat efektif.

Kata kunci: Potensi, Efektifitas, Jumlah wisatawan, Jumlah hotel, Pajak hotel, Penerimaan pajak hotel 


\begin{abstract}
Analysis of Potential and Effectiveness Hotel Tax and Factors which Affecting Hotel Tax Income in Bandung City

By:

Muhamad Iqbal Naimul Firdaus
\end{abstract}

1506710

\title{
Advisor: \\ Budi S. Purnomo, S.E.,MM.,M.Si.,CACP
}

This study aims to determine how much the effect of potential and effectiveness of hotel tax in Bandung City on 2016-2018 and analyzing factors that affect tax revenues in Bandung City. The research method used in this research is descriptive with quantitatif method. The population in this study are all hotels in Bandung City. The sampling method in this study used saturation sampling. Secondary data was collected from Government Instance Performance Report during 2004-2018. To examine the hypothesis used multiple linear regression analysis with SPSS software tools. The result of hypothesis testing show that (1) the number of tourists have a positive effect on tax revenues (2) the number of hotels haven't effect on tax revenues. Based on calculation of potential and effectiveness, the result is that the potential of hotel taxes in Bandung City is smaller than the realization of hotel taxes, which means hotel tax collection in Bandung City is optimal, and effectiveness of hotel tax which is always above 100\%, which means the level of effectiveness is very effective.

Keywords : Potential, Effectiveness, Tourist amount, Hotel amount, Hotel tax, Hotel tax income 


\section{KATA PENGANTAR}

Segala puji dan syukur penulis panjatkan kepada Tuhan Yang Maha Esa atas segala berkah dan kehendak-Nya, sehingga penulis dapat menyelesaikan penyusunan Proposal Usulan Penelitian dengan judul "Analisis Potensi dan Efektifitas Pajak Hotel Serta Faktor-Faktor yang Mempengaruhi Penerimaan Pajak Hotel di Kota Bandung". Proposal usulan penelitian ini disusun dengan tujuan pemenuhan salah satu syarat memperoleh Sarjana Ekonomi pada Program Studi Akuntansi Universitas Pendidikan Indonesia.

Dalam penyusunannya penulis tidak mengingkari bahwa terdapat beberapa kendala yang menghambat penyusunan proposal usulan penelitian ini. Namun berkat bantuan dari berbagai pihak penulis dapat mengatasi kendala-kendala tersebut. Oleh karena itu, dengan ini penulis sampaikan ungkapan terima kasih sebesar-besarnya kepada seluruh pihak yang telah membantu kelancaran penyusunan proposal usulan penelitian ini.

Penulis menyadari bahwa penyusunan proposal usulan penelitian ini masih jauh dari kesempurnaan. Oleh karena itu penulis sangat mengharapkan kritik dan saran membangun dari para pembaca sekalian sebagai bahan untuk perbaikan penulis kedepannya. Besar harapan penulis semoga prorposal usulan penelitian ini dapat bermanfaat bagi para pembaca sekalian terutama bagi penulis.

Terima kasih.

Bandung, Mei 2019

Penulis 


\section{DAFTAR ISI}

\section{LEMBAR PENGESAHAN}

PERNYATAAN KEASLIAN NASKAH

UCAPAN TERIMAKASIH

\section{ABSTRAK}

ABSTRACT

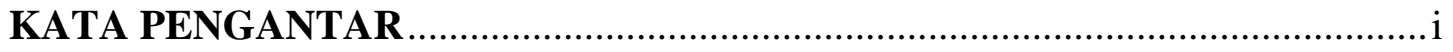

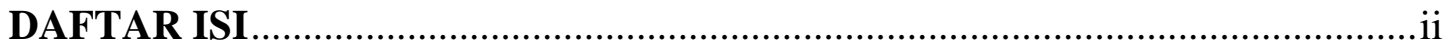

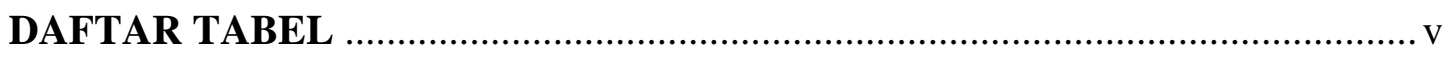

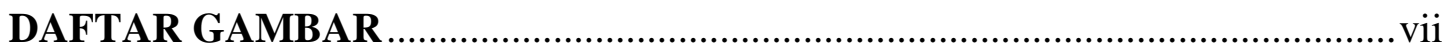

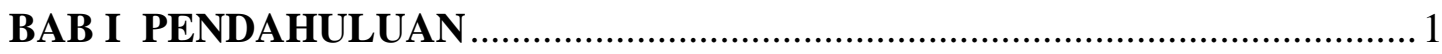

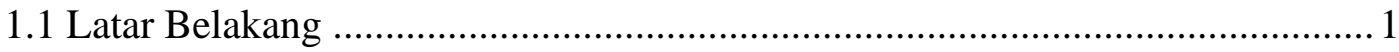

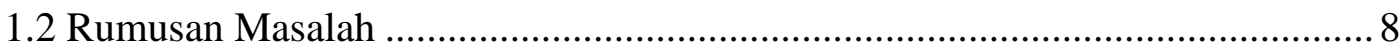

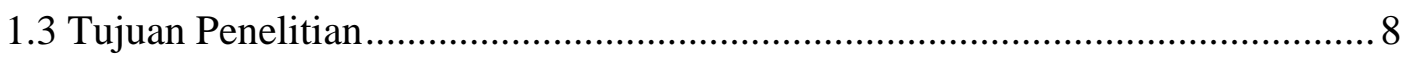

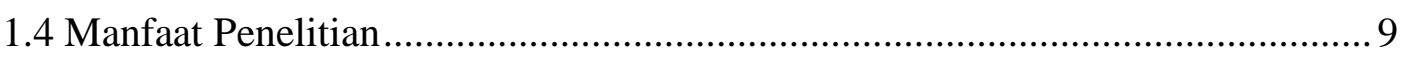

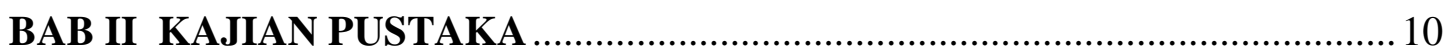

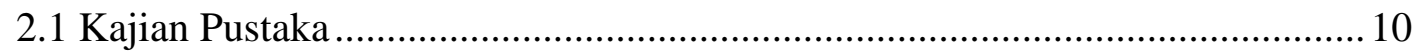

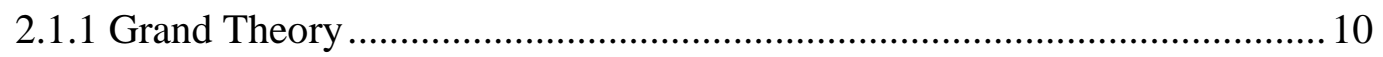

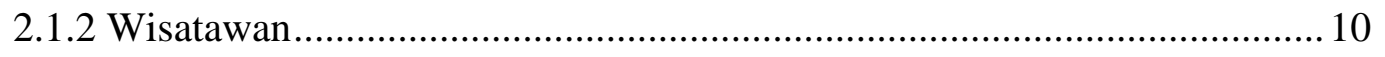

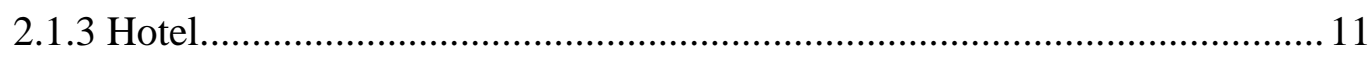

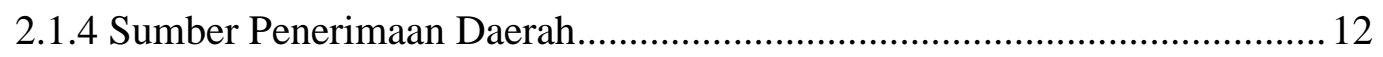

2.1.5 Pendapatan Asli Daerah........................................................................... 13

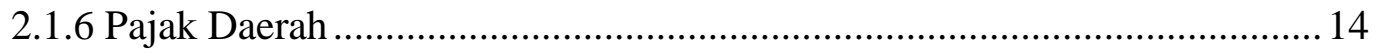

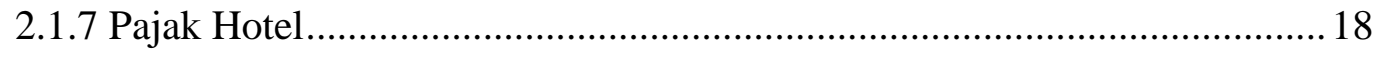

2.1.8 Potensi dan Efektifitas Pajak Hotel .......................................................... 21

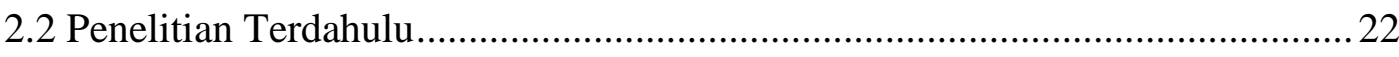

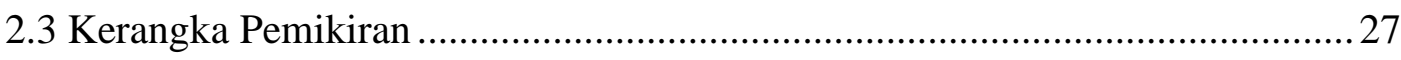

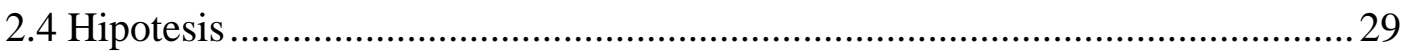

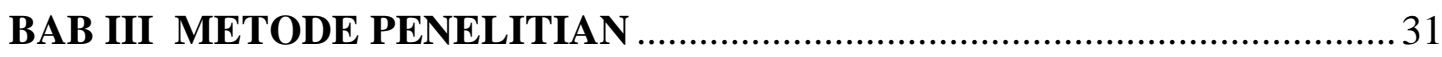

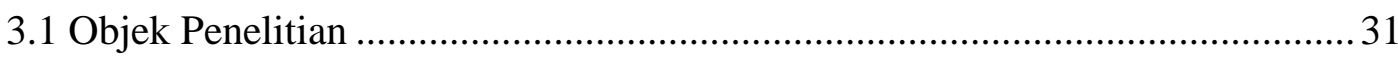




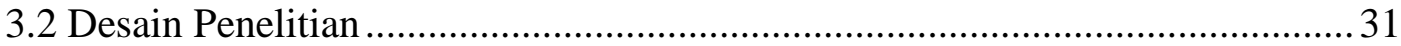

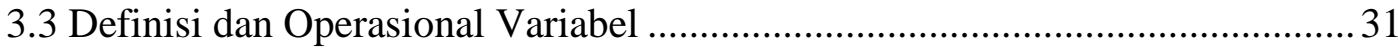

3.3.1 Variabel Independen ................................................................................. 32

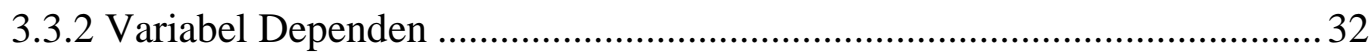

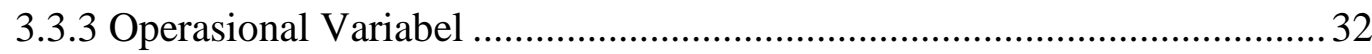

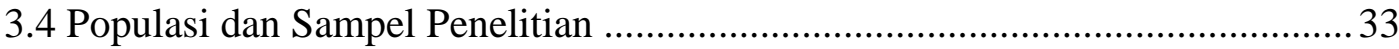

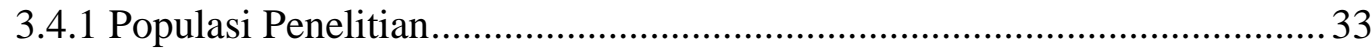

3.4.2 Sampel Penelitian ..................................................................................... 33

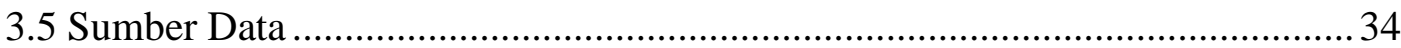

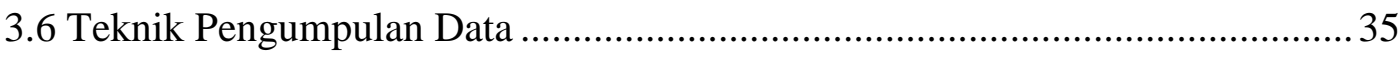

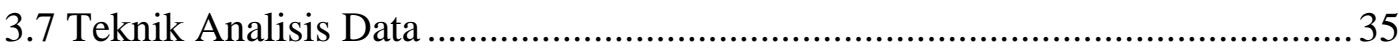

3.7.1 Perhitungan Potensi Pajak Hotel.................................................................. 35

3.7.2 Analisis Perhitungan Efektifitas Pajak Hotel...............................................36

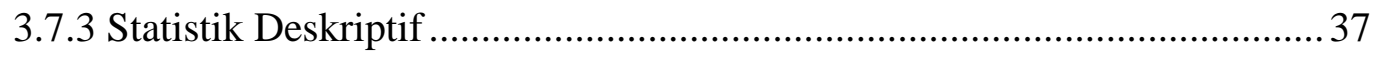

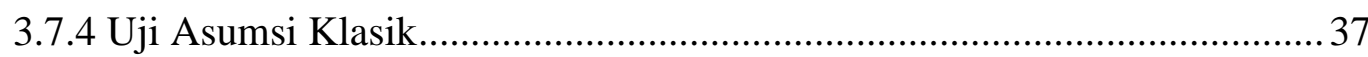

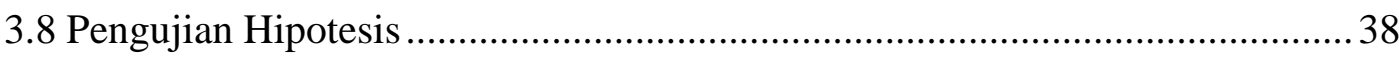

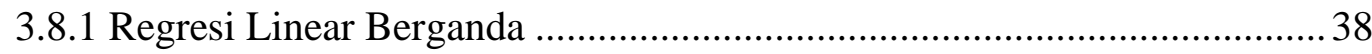

3.8.2 Uji Kelayakan Model............................................................................ 39

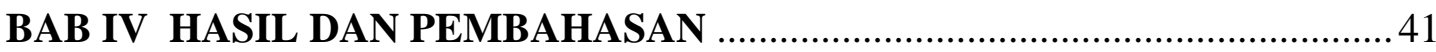

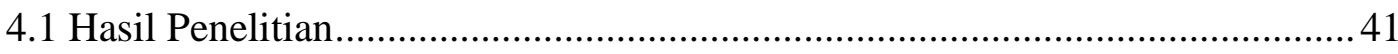

4.1.1 Gambaran Umum Subjek Penelitian........................................................... 41

4.1.2 Deskriptif Data Variabel ............................................................................4

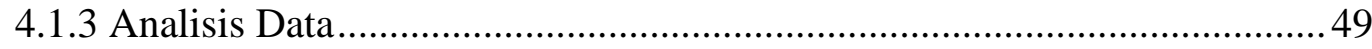

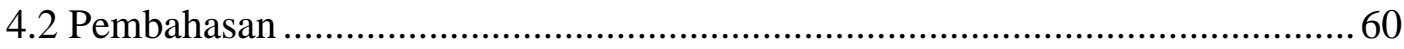

4.2.1 Potensi Penerimaan Pajak Hotel di Kota Bandung ........................................60

4.2.2 Efektifitas Penerimaan Pajak Hotel di Kota Bandung ..................................62 62

4.2.3 Pengaruh Jumlah Wisatawan terhadap Penerimaan Pajak Hotel di Kota

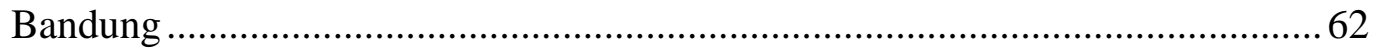

4.2.4 Pengaruh Jumlah Hotel terhadap Penerimaan Pajak Hotel di Kota

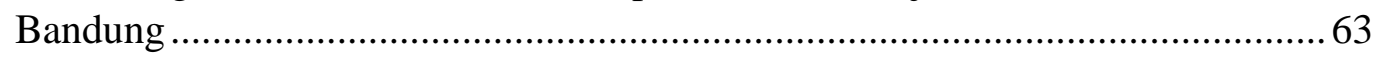

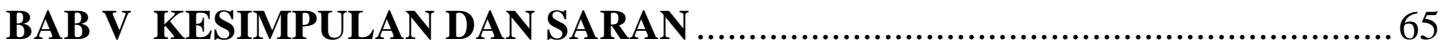

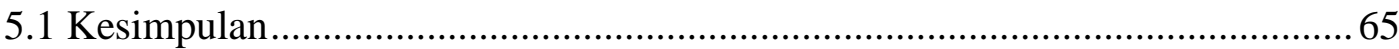




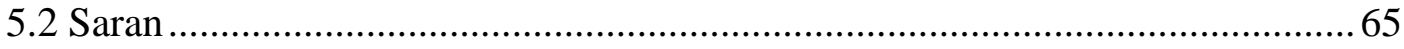

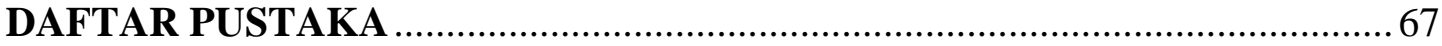

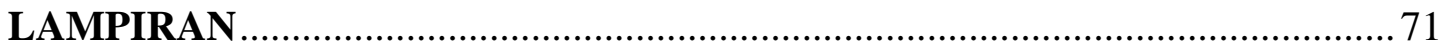




\section{DAFTAR TABEL}

Tabel 1.1 Realisasi Pajak Daerah Kota Bandung Tahun 2015-2018 .....................3

Tabel 1.2 Jumlah Kunjungan Wisatawan Kota Bandung Tahun 2004-2018 ..........4

Tabel 1.3 Jumlah Hotel di Kota Bandung Tahun 2004-2018...............................5

Tabel 1.4 Target dan Realisasi Pajak Hotel Kota Bandung Tahun 2015-2018.......5

Tabel 2.1 Penelitian Terdahulu.........................................................................22

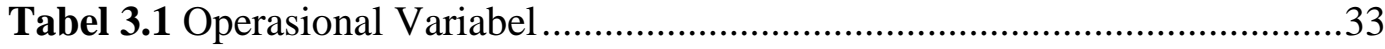

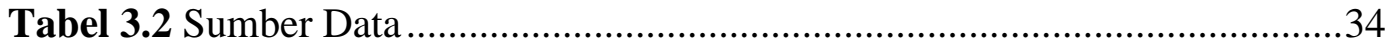

Tabel 4.1 Jumlah Hotel di Kota Bandung Tahun 2004-2018 .............................43

Tabel 4.2 Jumlah Kamar Hotel di Kota Bandung Tahun 2016-2018 ...................44

Tabel 4.3 Rata-Rata Tingkat Hunian Kamar Hotel di Kota Bandung Tahun

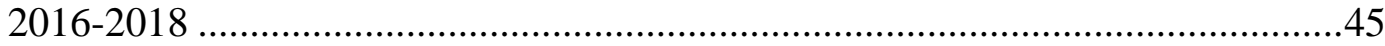

Tabel 4.4 Harga Rata-Rata Kamar Hotel di Kota Bandung Tahun 2016-2018.....45

Tabel 4.5 Statistik Deskriptif Jumlah Wisatawan di Kota Bandung Tahun 2004

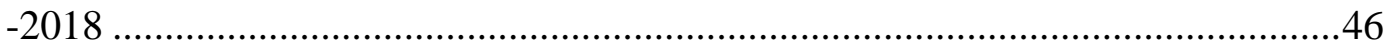

Tabel 4.6 Statistik Deskriptif Penerimaan Pajak Hotel Kota Bandung Tahun 2004-2018

Tabel 4.7 Jumlah Kamar di Kota Bandung Tahun 2016-2018

Tabel 4.8 Tarif Kamar Rata-Rata dan Tingkat Hunian di Kota Bandung Tahun 2016-2018 .49

Tabel 4.9 Perhitungan Potensi Pajak Hotel Kota Bandung Tahun 2016..............50

Tabel 4.10 Perhitungan Potensi Pajak Hotel Kota Bandung Tahun 2017 .............50

Tabel 4.11 Perhitungan Potensi Pajak Hotel Kota Bandung Tahun 2018.............51

Tabel 4.12 Perhitungan Efektifitas Pajak Hotel Kota Bandung Tahun 20162018

Tabel 4.13 Hasil Uji Normalitas. .52

Tabel 4.14 Tabel Hasil Uji Multikolinearitas .....................................................54

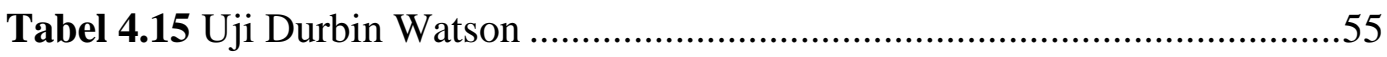

Tabel 4.16 Output SPSS Regresi Linear Berganda ..........................................56

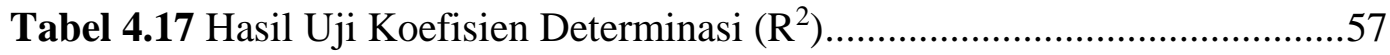

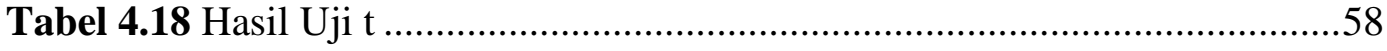


Tabel 4.19 Hasil Uji F

Tabel 4.20 Potensi Penerimaan Pajak Hotel di Kota Bandung Tahun 2016-

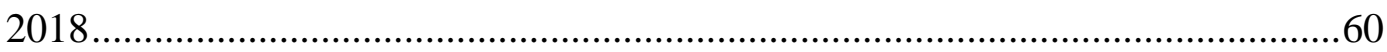

Tabel 4.21 Target, Realisasi, dan Potensi Pajak Hotel Kota Bandung Tahun 2016-2018 .60

Tabel 4.22 Efektifitas Penerimaan Pajak Hotel Kota Bandung Tahun 2016 2018 61 


\section{DAFTAR GAMBAR}

Gambar 2.1 Rumus Perhitungan Potensi Pajak Hotel ......................................21

Gambar 2.2 Perhitungan Efektifitas Pajak Hotel..............................................22

Gambar 2.3 Kerangka Pemikiran .........................................................29

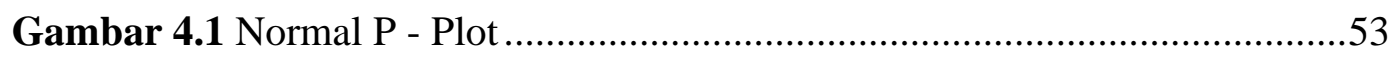

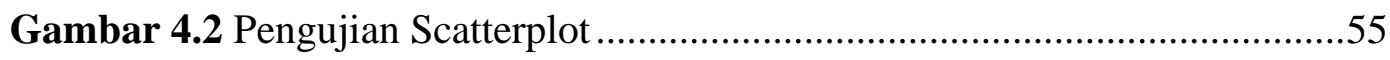




\section{DAFTAR PUSTAKA}

\section{Perundang-Undangan}

Undang-Undang Nomor 33 Tahun 2004 Tentang Perimbangan Keuangan Antara Pemerintah Pusat dan Pemerintah Daerah

Undang-Undang Nomor 28 Tahun 2009 Tentang Pajak Daerah dan Retribusi Daerah

Undang-undang Nomor 23 Tahun 2014 tentang Pemerintahan Daerah

Peraturan Pemerintah Nomor 55 Tahun 2016 tentang Ketentuan Umum dan Tata Cara Pemungutan Pajak Daerah

Peraturan Menteri Dalam Negeri Nomor 13 Tahun 2006 tentang Pengelolaan Keuangan Daerah

\section{Buku dan Artikel Jurnal}

Adam, Aldo. (2011). Hubungan Jumlah Wisatawan, Jumlah Hotel Terhadap Penerimaan Pajak Hotel. Jurnal EMBA 1(3), 664-672.

Ali, Syadzali Hadji., Engka, D. S. M., \& Rompas, W. F. I. (2018). Analisis FaktorFaktor yang Mempengaruhi Penerimaan Pajak Hotel di Kota Bitung. Jurnal Berkala Ilmiah Efisiensi 18(05), 143-151.

Ardhiansyah, Diaz., Rahayu, Sri Mangesti., \& Husaini, Achmad. (2014). Analisis Potensi Pajak Hotel dan Pajak Restoran dan Kontribusinya Terhadap Pendapatan Asli Daerah (PAD) ( Studi Kasus pada Dinas Pendapatan Daerah Kota Batu Tahun 2011-2013 ). Jurnal Administrasi Bisnis (JAB), 14(1).

Arikunto, S. (2013). Dasar-Dasar Evaluasi Pendidikan, Edisi 2. Jakarta: Bumi Aksara.

Carl, Bonham, Edwin Fuji. (1992). The Impact Of The Hotel Room Tax: An Interrupted Time Series Approach. National Tax Journal, Vol. 45, No. 4, pp. 433-441

Darise, N. (2009). Pengelolaan Keuangan Daerah. Jakarta: PT.Indeks. 
Darwin. (2010). Pajak Daerah dan Retribusi Daerah. Jakarta: Mitra Wacana Media.

Dwi, Vidya Aliandi, A., \& Handayani, H. R. (2013). Pengaruh Jumlah Wisatwan, Jumlah Hotel, dan Tingkat Hunian Hotel Terhadap Penerimaan Pajak Hotel (Studi Kasus pada Kota Yogyakarta). Diponegoro Journal of Economics 2, 114.

Edwin, Futji, Mohamad Khaled, \& James Mak. (1985). The Exportability of Hotel Occupancy and Other Tourist Taxes. National Tax Journal, Vol. 38 No 2 pp. 169-177

Ghozali. (2017). Aplikasi Analisis Multivariate dengan Program IBM SPSS 23. Semarang: Badan Penerbit Universitas Diponegoro.

Hesty Reny Tonapa, David Saerang, L. M. (2017). Analisis Potensi, Efektifitas, dan Kontribusi Pajak Hotel Terhadap Pendapatan ASli Daerah Kabupaten Tana Toraja. Jurnal Riset Akuntansi Going Concern, 12(1), 130-138.

J. H. Davis, F. David Scoorman dan L. Donalson. 1997. "Toward a Stewardship T heory of Management." Academy of Management Review Vol. 22, No. 1, pa ge 22-47.

J. Paul Combs \& Barry W Elledge. (1979). Effects of a Room Tax on Resort Hotel. National Tax Association, Vol. 32, No. 2, pp. 201-207.

James J. Spillane. 1991. Ekonomi Pariwisata: Sejarah dan Prospeknya. Yogyakarta: Kanisius

James, Mak \& Edward Nishimura. (1979). The Economics of a Hotel Room Tax. Journal of Travel Research, 17(4), 2 -6.

Larry, Yu \& Gu Huimin. (2005). Hotel Reform in China. Cornell Hotel and Restaurant Administration Quarterly, 46 (2), 153-169

Mahmudi. (2010). Manajemen Keuangan Daerah. Jakarta: Erlangga

Mardiasmo. (2002). Akuntansi Sektor Publik. Yogyakarta: ANDI.

Prakosa, B. (2005). Pajak dan Retribusi Daerah. Yogyakarta: UII Press. 
Pujiasih, Rofian., \& Wardani, D. K. (2017). Analisis Potensi, Efektifitas Dan Kontribusi Pajak Hotel Terhadap Pendapatan Asli Daerah Kabupaten Sleman. Jurnal Akuntansi, 2(2), 130-138.

Putu Widyaningsih, M. K. S. B. (2014). Pengaruh Jumlah Kunjungan Wisatawan Terhadap Penerimaan Pajak Hotel, Pajak Restoran, dan Pendapatan ASli Daerah. E-Jurnal Ekonomi Pembangunan Universitas Udayana, 3(4), 155163.

Raharjo, Eko. (2007). Teori Agensi dan Teori Stewarship Dalam Perspektif Akuntansi. Fokus Ekonomi, 2(1), 37-46.

Rumekso. (2002). Housekeeping Hotel. Yogyakarta: Andi

Sabatini, Rifqy., \& Purwanti, E. Y. (2013). Analisis Faktor-Faktor yang Mempengaruhi Penerimaan Pajak Hotel di Kota Semarang. Diponegoro Journal of Economics, 2(1), 1-7.

Sanusi, A. (2011). Metodologi Penelitian Bisnis. Jakarta: Salemba Empat.

Sedana, I. K. A., Artana, M., \& Suwena, K. R. (2013). Efektivitas Dan Kontribusi Pajak Hotel Dan Pajak Restoran Terhadap Pendapatan Asli Daerah (Pad) Di Kabupaten Gianyar Tahun 2008-2012. Jurnal Pendidikan Ekonomi Undiksha, 3.

Sekaran. (2011). Research Methods for Business, Edisi 1 dan 2. Jakarta: Salemba Empat.

Siahaan, M. P. (2010). Pajak Daerah \& Retribusi Daerah (Revisi). Jakarta: Rajawali Pers.

Sugiyono. (2017). Metode Penelitian Pendidikan: Pendekatan Kuantitatif, Kualitatif, dan R\&D. Bandung: Alfabeta.

Supit, Novia. L., \& Kumenaung, A. G. dan R. L. H. T. (2015). Analisis FaktorFaktor yang Mempengaruhi Penerimaan Pajak Hotel di Kota Manado. Jurnal Berkala Ilmiah Efisiensi, 15(03), 198-209.

Tunggal, A. W. (1991). Pelaksanaan Pajak Penghasilan Perseorangan. Jakarta: 
Rineka Cipta.

Yayuk. (1992). Teori dan Petunjuk Praktek Housekeeping Untuk Akademi Perhotelan. Make Up Room. Jakarta: Gramedia Pustaka Utama. 